\title{
Early childhood pedagogy in a Ghanaian socio- cultural medley: A case study of two Kindergarten classrooms
}

\section{Thompson Mumuni}

Department of Basic Education. College of Education Studies. Faculty of Educational Foundations. University of Cape Coast. Ghana. Email: tmumuni@ucc.edu.gh.

\begin{abstract}
In a quest for quality-driven early childhood education settings, it is important to explore subtleties that define socioculturally-relevant pedagogy that is often ignored in scholarly literature. To address this gap in literature, a qualitative multicase study approach was used to explore four kindergarten teachers views regarding early childhood pedagogy over a sixmonth in kindergarten classrooms in Tata School and at Kariba School. This study sought to establish "Why does children's sociocultural contexts influence choice of pedagogy in kindergarten classrooms". The study was framed by Bronfenbrenner's framework, ecological theory. The sources of data comprised semi-structured individual interviews, pair-interviews and field notes of classrooms observations. Both within and across case interpretative analysis was used. The study established that, participants in the two cases perceived that a socio-cultural context-based pedagogy such as learning materials, storytelling, traditional songs and traditional rhymes supported children's development in terms of their understanding of concepts, language development, cognitive and moral development, respectively.
\end{abstract}

Keywords: Pedagogy theory; Socio-cultural context; Teachers; Teaching; Ghanaian schools; Education; Human Ecology.

Resumo. Pedagogia da primeira infância em um mix sociocultural ganense: um estudo de caso de duas salas de aula de Jardim de Infância. Numa busca por ambientes de educação infantil voltados para a qualidade, é importante explorar sutilezas que definem a pedagogia socioculturalmente relevante que é frequentemente ignorada na literatura acadêmica. Para abordar esta lacuna na literatura, uma abordagem qualitativa de estudo de casos múltiplos foi usada para explorar quatro visões de professores de Jardim de Infância sobre a pedagogia da primeira infância durante seis meses nas salas de aula do Jardim de Infância na Escola Tata e na Escola Kariba. Este estudo procurou responder o "Porquê dos contextos socioculturais das crianças influenciam a escolha da pedagogia nas salas de aula do Jardim de Infância". 0 estudo foi enquadrado
Received:

December 5, 2018

Accepted:

April 21, 2019

Released:

April 30, 2019

Full Text Article

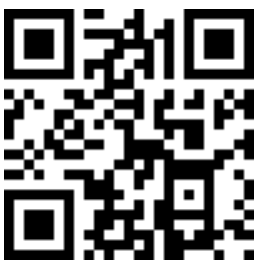

ORCID

(1) 0000-0001-7480-6849 Thompson Mumuni 
pelo Arcabouço de Bronfenbrenner, e pela teoria ecológica. As fontes de dados compreenderam entrevistas individuais semiestruturadas, entrevistas em pares e notas de campo das observações das salas de aula. Tanto dentro como entre a análise interpretativa de caso foram usados. 0 estudo estabeleceu que os participantes dos dois casos perceberam que uma pedagogia sociocultural baseada no contexto, como materiais didáticos, contação de histórias, canções e rimas tradicionais, apoiavam o desenvolvimento infantil em termos de compreensão de conceitos, desenvolvimento da linguagem, desenvolvimento cognitivo e moral, respectivamente.

Palavras-chave: Teoria da pedagogia; Contexto sociocultural; Professores; Ensino; Escolas ganenses; Educação; Ecologia Humana.

\section{Introduction}

The content of instructional practices of a pedagogue in early childhood settings is largely informed by theoritical insights of several theorists (Dewey, 1902; Piaget, 1952; Vygotsky, 1957; Erickson and Maslow, 1975, Bronfenbrenner, 1979). Some of these theorists have theorised the significance of developmentally appropriate pedagogy which is anchored on the provision of thought-provoking learning experiences, culturally situated learning, constructivist approach to learning and individual children-focused approach to learning. Research evidence (Piaget, 1952; Vygotsky, 1957) suggests that a child's development is largely influenced by a process of cognitive construction and that can only be attained when the learner is actively engaged within the context of activity-based learning settings. In effect, instructional processes that are child-centred and driven by an instructional approach, that sees the child as a complex socio-cultural defined being bursting with rich and unique potentials tend to deal with the differential learning needs of children.

Children need adult support in diverse ways (Thompson, 2018) before the uniqueness that each of them brings to the learning context can be unearthed and developed through instructional approaches which are in tune with the nature of children and how they learn. As a professional, a pedagogue is expected to be a reflective practitioner by applying instructional practices largely informed by theoretical insights and in-depth knowledge and understanding regarding how to resolve seemingly, intractable challenges they are likely to encounter in their practice (Veale, 2014). The question that arises is the significance of these insights to a pedagogue. Every child comes to learning context with certain uniqueness and each of them requires appropriate responses based on a teacher's knowledge and understand regarding the developmental needs of individual children. Research evidence suggests (Siraj-Blatchford et al., 2002) that the individuality children bring to the learning context is largely shaped by the quality of learning experiences children gain from both the classroom and the home contexts. In effect, teaching and learning process and its efficacy to some is extent is dependent on the pedagogue in terms of insights, regarding learning needs, individual differences and the uniqueness that each child brings to the learning contexts. These insights are significant, because it gives the early childhood educator nuanced understanding regarding choice of an effective pedagogy that is in sync with nature of children and how they 
learn. This is not surprising, because the choice of a child-friendly pedagogy leads to the creation of an interactive learning environment which in turn, help children accomplish tasks through a corroborative effort which is often characterized by shared-thinking.

Even though, wide-ranging academic research has investigated the influence of early childhood pedagogy as one of the most significant drivers of children's development (Gananathan, 2011; Harris, 2015; Farquhar and White, 2014; Hedges and Cullen, 2012; Murray, 2015; Winterbottom and Mazzocco, 2015) much less research has explored early childhood pedagogy and its attendant contribution to children's development in diverse ways within the West-African sub-region. Besides, earlier studies focused on differing sociocultural contexts so these studies are silent regarding the extent to which children's socio-cultural settings influence selection of pedagogy and the significance therein. Moreover, one of the previous studies (Winterbottom and Marzocco, 2015) employed quantitative research to explore the phenomenon in question whereas the rest of the other studies mentioned earlier are position papers. This gap in literature needs to be filled. In light of this, there is an incomplete picture regarding how early childhood pedagogy influence children's development in early childhood settings. A nuanced research is required to understand the extent to which early childhood pedagogy supports children's development in diverse ways. In response to the growing need to have insights regarding the extent to which an early childhood which socio-culturalcontext specific tends to influence children's development in diverse ways. A qualitative case study research approach was used to explore the phenomenon in question. Against this background, the purpose of this research is to answer the research question: Why does children's socio-cultural contexts influence choice of pedagogy in kindergarten classrooms?

Accordingly, this study's findings provide early childhood educators, researchers, and other stakeholders (e.g. curriculum developers) insights regarding how children's sociocultural contexts can and do influence early childhood pedagogy teachers deem appropriate for their children in kindergarten settings. Since much of what these teachers shared aligned with the curriculum, these findings provide evidence to policy makers in Ghana that individual teachers, with differing educational backgrounds, appear to apply early childhood pedagogy taken into account children's socio-cultural contexts. Likewise, though, it is significant that these teachers felt sufficient agency to modify and adapt the pedagogy in ways they believed made sense locally.

\section{Theoretical framework}

Bronfenbrenner

ecological theory framed the current study. The theory provides insights regarding how the interactions between a child and the child's socio-cultural context serve as basis for human development. The theory sheds new views regarding the developing child, the socio-cultural context of the child as well as the emerging relations between the two. In effect, a synergy between the triadic relations forged between these agents tend to enhance and promote children's development in diverse ways. This is not surprising because the ecological milieu is seen as a layer with its attendant diverse structures. At the inmost level, is the socio-cultural contexts of the developing child. This might either be the home or the school settings. It does appear that through adult support, the child applies sociocultural tools such as language and literacy to make meaning of their everyday experiences within the 
classroom context. This is significant, because instructional processes which are often defined by socio-culturallysituated and relevant early childhood pedagogy tend to promote children's development. This suggests that an early pedagogy which is largely informed by context-specific learning materials, storytelling and rhymes when used in kindergarten are likely to help children understand and gain new experiences which in turn, promote their development.

The third stage regarding the ecological environments perceives that a child's development is greatly influenced by factors beyond a child's immediate environment. More importantly, children's development is not influenced by their socio-cultural contexts (Rogoff, 2009) alone but also, by best practices drawn from other socio-cultural contexts across the globe such as the use of childfriendly information and communication technology devices to enhance effective teaching and learning in kindergarten class which in turn, lays a sound foundation regarding making young children technologically savvy and creative. More importantly, it further provides insights regarding how early childhood educators can promote children's holistic development in diverse ways which invariably form a critical part regarding the essence of kindergarten education across the globe. Nevertheless, the current study focuses on the first and the second levels of the theory because the research aims at establishing the kinds of early childhood pedagogy used in early childhood settings with the study contexts and the significance therein.

The paper comprises three sections. Initially, the research methodology is presented. Data are analysed on case by case basis. Data are further analyses across cases. Next, the findings are discussed. The paper concludes with a discussion of theoretical implications, implications for practice and conclusion.

\section{Method}

\section{Participants}

The study consisted of four participants (Kate and Sophia from Tata School; Ramatu and Akotia from Kariba School) purposively sampled from two kindergarten classrooms sited in different socio-economic contexts within the Cape Coast Metropolis, Ghana. Kate, has taught for 25 years while Sophia has taught for 19 years. Ramatu has taught for, nine years, Akotia on the other hand has taught for seven years. While both Kate and Sophia have bachelors' degrees in early childhood education, Ramatu and Akotia on the other hand, have diploma in early childhood education. A multi-case qualitative study approach was used in this study because the thrust of the study was to establish the differences regarding teachers' practices in Tata School and Kariba School sited in different socio-economic settings.

\section{Instruments}

Two main instruments were used for this study. These included semistructured interviews and observations. The interviews made it possible for the researcher to gain insights into participants' perspectives about their practices in kindergarten classrooms. The participants were interviewed in pairs once and individually twice. Interviewing teachers in pairs provided a platform for them to share their rich experiences with each other and the researcher as well. Other reasons for interviewing the participants several times included the following; first, it enabled me to establish the consistencies of the responses of the participants across the interview sessions. It allowed for the interviewees to talk at length and elaborate because they were given the opportunity to react to questions 
multiple times. It allowed the interviewees to talk at length and elaborate because they were given the opportunity to react to questions multiple times. The interviews were conducted at a time when children were on break. In all, each of the visits to the classrooms lasted one hour. In the second phase, observation took place in all the two kindergarten classrooms. After the transcriptions of the interviews, the teachers were given opportunity to cross-check whether the transcripts reflect their views (member checking). The observations provided an opportunity for me to determine how teachers level of knowledge about their practices unfolded in real-life classroom context. During my observations, on occasion, and in an unobtrusive manner as possible, I conversed with the kindergarten teachers while the children were engaged in certain small group activities or individual activities to seek clarifications from them reasons for engaging children in various kinds of activities. After, the end of every lesson, I engage them in a discussion for about ten minutes to seek further clarifications on certain issues. This process of interacting with the teachers provided each one of them an opportunity to clarify an issue that was perplexing to me arising while observing the teachers' instructional practices in the classrooms. That is during these sorts of activities, each of the teachers were seen moving from one group to another giving guidance to the children on how to accomplish a task whenever any of them encountered a challenge. This method provided an opportunity for me to observe and interact with the teachers two or three times during the study. Because my focus in this study is to explore teachers' perspectives about their practices in the classrooms. Field notes rather than recording, reduced such intrusions. Such observations allowed me to enactment of issues beyond self-reporting because how teachers describe their actions and how their actions unfold in real-life teaching and learning context differ. The observations of the teachers were done after each of the teachers have been interviewed. Apart from been a technique of for generating primary data, observations serve as a check on the other data collection method. This method was used to check individual biases that likely to be exhibited in the in-depth interviews. Also, the gathering of data using two research instruments allow for triangulation of data.

\section{Procedure}

The instruments were administered to the participants in the two case schools from May 2015 to November 2015. The data analyses were on case by case basis to identify key themes within each of the cases to answer the research questions. The teachers' thoughts were audio recorded and transcribed verbatim. The teachers' thoughts were further organised into categories. The themes that emerged from the analyses were further validated by the observational data. In short, the themes were determined through open and axial coding (Boeije, 2010). From the analyses above, it can be concluded that a theme is a pattern across data sets that is important to the description of a phenomenon which is linked to a research question.

\section{Data quality measures}

The current article is an extract from my $\mathrm{PhD}$ dissertation was conceived and carried out by me with assistance from my supervisory committee. This research received approval from the University of British Columbia's (UBC) Behavioural Ethics and Research Board (ethics certificate number H15-00364). In this study, the four measures for ensuring trustworthiness include; the use of diverse data sources (triangulation), debriefing, member checking, and thick description of the issues explored. 


\section{Results}

In particular, the study's results are reported as follows: the case of two teachers at the southern school, Tata; the case of two teachers at the northern school, Kariba; and finally, a cross-case analysis.

Case study analyses of the teachers at the Southern School (Tata)

At Tata School, both kindergarten teachers used early childhood pedagogy such as learning materials, stories or traditional songs as their means of situated learning within the sociocultural contexts of children in kindergarten classrooms.

\section{Learning Materials and children's socio-cultural context}

The teachers at Tata School believed learning materials were useful regarding helping children understand concepts taught in a kindergarten classroom. That is, Kate and Sophia revealed that their children's backgrounds guided their selection of learning materials. For example, they each explained the need to translate materials such as a conversational poster or environmental print (i.e. labels from children's everyday experiences).

Kate: I consider their background, and their background is English. So, it becomes the basis for selecting learning materials. For instance, if I'm teaching the speaking and listening aspects of literacy, I use NALAP materials such as a conversational poster which is written in Fante language with pictures depicting activities within the local context. But whatever I do in class concerning the poster, I have to translate it into English language before they can understand what I am teaching.

Sophia: I used materials that can be found easily in the children's immediate environment. But I have to translate the materials which are in Fante into the English Language before we can use them because the children see these materials in their environment, but they do not know what they are. If it is real materials that I'm using, I have to translate from Fante language into the English Language to help them understand the concept better. But as time goes on, I use the mother tongue and the English language to explain concepts.

Interestingly, then, because their children did not understand the Fante language, these teachers saw the need to translate concepts contained within the materials from the Fante language into the English language. Thus, this allowed their children to draw meaning from whatever learning experiences they had in class, even though, the learning materials selected from the children's environment and supplied by the curriculum were meant to align with the children's sociocultural settings.

Both Kate and Sophia perceived that children's sociocultural contexts should serve as a basis for the selection of learning materials. However, the teachers perceived the impact of these contexts on children's development differently. For Kate, "it helps children understand their environment" while for Sophia, "children learn better if learning materials are selected from their immediate environment." Thus, Kate's perception about learning materials appeared to suggest that because children's environment informs the selection of learning materials, it helps them understand their environment, while Sophia, on the other hand, believed that the use of real objects helps children understand concepts taught in class. Overall, for Kate and Sophia, learning occurs in kindergarten settings when the teacher provides an opportunity for children to relate what they are currently learning to what they already know from prior experiences using familiar materials. 


\section{Storytelling from Ghanaian socio-cultural perspectives}

Both teachers, from Tata School, believed that storytelling was an effective means of making learning meaningful and relevant to their children in kindergarten classrooms. For example, Kate perceived that storytelling " helps a child develop moral values which are acceptable to a child's social context" and Sophia believed that storytelling "helps pass on the norms of society to the younger ones."

Indeed, for both teachers, storytelling was an effective means of promoting children's moral development because it provided an opportunity for children to make meaning of their daily experiences. Thus, storytelling provided an opportunity for children to see themselves through others by relating with the characters in the story and commenting on the characters' essential life experiences in relation to accepted norms of society.

However, the teachers saw the means of interpreting and applying storytelling in kindergarten classrooms differently.

Kate: I show them pictures for them to tell me the moral lesson connected to a particular episode in the story. If it is about unacceptable conduct such as a character using the left hand to collect something or greet someone, I ask the children to comment on the behaviour of the character.

Sophia: If the story is about 'Ananse and the wisdom pot,' some of the children would not know what an earthenware pot is about because they come from different homes. So, to make the story meaningful to them, I usually bring a pot to class. And as I narrate the story, I let them look at the pot and say something about it, and then I relate it to the modern version of the cooking pot which is common in homes where the children are coming from.
For Kate, children understand concepts taught in class better if the teacher does the explanation in such a way that there is a linkage between the concept and a corresponding physical entity that the child has previously encountered or is yet to encounter. Thus, for storytelling to have the desired impact on children's development, the teacher incorporated familiar physical objects to enhance and promote children's comprehension which in turn, impacted children's morals development. However, in the case of Sophia, when using storytelling, she sought ways to provide an opportunity for the children to draw linkages between the items in the story (e.g. the pot) and their corresponding real-life objects so that they can understand the story.

Both Kate and Sophia perceived that a story could be meaningful to children if it is presented to them in inventive ways.

Kate: I dress and behave like the main character in the story and at every stage of the story.

Sophia: Storytelling helps the children to relate to their environment. For, example, one of the children might be sent to the market by someone to buy something, but in the market, the women will not be able to speak the English Language with him or her. But the child might see certain things that he or she wants to buy but cannot communicate with those in the market. So, I introduce Fante names of certain objects found in their environment into the stories so as they listen to the stories the names of these objects would be emphasised to help them become functional their environment.

Through imitation of traits of characters in a story, Kate promoted the development of her children. Sophia, on the other hand, enabled her monolingual children to relate with others in their community by explaining the English 
language version of certain concepts in the Fante language through stories thereby exposing her kindergarteners to the Fante language, in order to increase their functionality in their environment.

\section{Making learning meaningful to children through traditional songs}

Kate and Sophia used traditional Ghanaian songs as tools for making learning meaningful in their kindergarten classrooms. While they agreed on the significance of songs to children's development, they disagreed on some specifics. For example, Kate and Sophia acknowledged the significant role traditional songs played in the children's acquisition of sounds of letter names in the English language.

However, only Kate related the use of traditional songs with supporting children's moral development. She elaborated:

Kate: It imparts moral values in young children. For example, there is a traditional song which goes like this; 'the young hawk's mother is dead but instead of finding work to do she goes about hunting for chickens. The meaning of the song is that if one does not work hard, one will end up [leading a wayward life]. To make the moral values of the song more meaningful to the children, I relate it to the everyday experiences of the children in a classroom setting by telling them that if they don't do their homework or assignment, it means they do not want to move to the next level.

Finally, my observations revealed that the two teachers (Kate and Sophia) used traditional songs (in the Tata school kindergarten classroom) as a tool for integrating children's learning experiences across subject areas. The teachers incorporated traditional songs into a play-based activity on several different activities that had a bearing on a lesson taught in class. The song usually emphasises key issues that underpinned the lesson, and as they sang the song, the teacher and children danced to the rhythms of the song. By composing a traditional song (songs commonly sung in the children's environment) such as "Sansakroma" (i.e. a song where the hawk's mother is dead but instead of leading a useful life he goes about stealing) concerning the lesson, the teacher appeared to do so for the purpose of promoting the holistic (i.e. the physical, social, emotional and moral) development of the children.

Overall, then, evidence from the data appears to suggest that the sociocultural context of children is a key determinant of what is appropriate for children to learn. However, to some extent, there exist diversity regarding how each teacher made learning relevant to children in this urban kindergarten settings, at the very least in the illustrative examples they provided.

Case study analyses of the
teachers at the Southern school (Tata)
At Kariba School, both
kindergarten teachers used early
childhood pedagogy such as learning materials, stories, traditional songs or rhymes as their means of situated learning within the socio-cultural contexts of children in kindergarten classrooms.

\section{Selecting learning materials from children's socio-cultural contexts}

The teachers at Kariba School used learning materials as one means of making learning relevant to children in their kindergarten classroom. For example, Ramatu and Akotia believed that children's socio-cultural contexts were one of the considerations that guided their selection of learning materials for their children. They explained:

Ramatu: I normally consider children's background by selecting learning materials which are 
common in children's environment. For example, many of the children help their mothers to sell vegetables and other items at the market. If the topic is about subtraction, I relate it [to] a market scene where the children help their mothers sell different kinds of vegetables such as tomatoes and garden eggs... As they engage in these activities in the market settings; they try to bring these experiences into the classroom context. And this helps them to understand concepts taught in class.

Akotia: I take into consideration the child's home environment because children learn better if learning materials used in class are familiar with them.

Moreover, Ramatu and Akotia perceived that children's socio-cultural contexts informed their selection of learning materials. Both teachers relied on their prior knowledge about the children, in selecting learning materials which are familiar to the children.

\section{Storytelling framed in children's socio-cultural contexts}

The teachers from Kariba School perceived storytelling as a means of situating learning within children's socio-cultural contexts, although, they perceived its impact on children's development differently.

Ramatu: Storytelling helps to develop the retentive memory of children because as children listen to stories, they narrate it to others. And as they do that at a point they will be able to narrate the story exactly as they heard it. It also helps them to develop listening skills.

Akotia: I use storytelling to promote the moral development of children. In recent times, some parents have shirked their responsibility as agents of moral development. So, it is the duty of the school which is one of the social institutions for moral development of children to use storytelling as a means of instilling moral values in children. For example, after taking the children through a storyline using a conversational poster, I ask the children to assess the behaviours of the characters in the story to determine whether the actions and the reactions of the characters were right or wrong.

$\begin{array}{clr}\begin{array}{c}\text { For } \\ \text { supported }\end{array} & \begin{array}{l}\text { Ramatu, } \\ \text { children's }\end{array} & \begin{array}{r}\text { storytelling } \\ \text { cognitive }\end{array}\end{array}$ development (i.e. the capacity to retain information) and listening skills. For Akotia, storytelling promoted children's moral development in kindergarten classrooms.

However, Ramatu and Akotia believed that there are inventive ways of presenting a story to maximise its impact on children's development. For example, Ramatu believed that storytelling could have the desired impact on children's development if the storyline is captured in a visual form. She explained:

Ramatu: I normally select stories from a book termed as 'the big book.' The book contains several traditional stories which are useful for children's moral development. The stories are in a pictorial form from one stage of the story to another. As I open the book, I ask them to describe the pictures and predict what is likely to happen in the next stage of the story [regarding the actions and inactions of characters in the story].

In a similar vein, Akotia perceived that stories captured in the form of picture imagery were both effective and appropriate for children's development. She explained:

Akotia: In this school, we have a book called 'the big book' which contains several traditional stories which are useful for developing certain values in children. The plot of the story is in a pictorial form with few inscriptions. 
Thus, both Ramatu and Akotia perceived that storytelling impacted children's moral development, especially, if the plot of the story is presented to children in a developmentally appropriate manner through visuals.

\section{Traditional songs and children's moral development}

Both Ramatu and Akotia from Kariba School used traditional songs as a pedagogy in their kindergarten classroom. However, the teachers did so for different reasons.

Ramatu: I use traditional songs in class to help the children integrate their learning experiences because, at the end of every lesson, I select some key issues that I emphasise in the lesson and compose a song. As we sing the song, we emphasise these issues, we jump, dance and shake our bodies in line with the lyrics of the song.

Akotia: I use storytelling to promote the moral development of children. In recent times, some parents have shirked their responsibility as agents of moral development. So, it is the duty of the school which is one of the social institutions for moral development of children to use storytelling as a means of instilling moral values in children. For example, after taking the children through a storyline using a conversational poster, I ask the children to assess the behaviours of the characters in the story to determine whether the actions and the reactions of the characters were right or wrong.

For Ramatu, storytelling supported children's cognitive development (i.e. the capacity to retain information) and listening skills. For Akotia, storytelling promoted children's moral development in kindergarten classrooms.

However, Ramatu and Akotia believed that there are inventive ways of presenting a story to maximise its impact on children's development. For example, Ramatu believed that storytelling could have the desired impact on children's development if the storyline is captured in a visual form. She explained:

Ramatu: I normally select stories from a book termed as 'the big book.' The book contains several traditional stories which are useful for children's moral development. The stories are in a pictorial form from one stage of the story to another. As I open the book, I ask them to describe the pictures and predict what is likely to happen in the next stage of the story [regarding the actions and inactions of characters in the story].

In a similar vein, Akotia perceived that stories captured in the form of picture imagery were both effective and appropriate for children's development. She explained:

Akotia: In this school, we have a book called 'the big book' which contains several traditional stories which are useful for developing certain values in children. The plot of the story is in a pictorial form with few inscriptions.

Thus, both Ramatu and Akotia perceived that storytelling impacted children's moral development, especially, if the plot of the story is presented to children in a developmentally appropriate manner through visuals.

\section{Traditional understanding enhancer \\ songs,}

Both Ramatu and Akotia from Kariba School used traditional songs in promoting children's development in their kindergarten classroom. However, the teachers did so for different reasons.

Ramatu: I use traditional songs in class to help the children integrate their learning experiences because, at the end of every lesson, I select some key issues that I emphasise in 
the lesson and compose a song. As we sing the song, we emphasise these issues, we jump, dance and shake our bodies in line with the lyrics of the song.

Akotia: It helps in building a child's vocabulary because while singing children role play some of the words in the song and this helps promote the language development of the children.

Thus, both Ramatu and Akotia perceived that storytelling impacted children's moral development, especially, if the plot of the story is presented to children in a developmentally appropriate manner through visuals.

\section{Traditional songs as means of}

Both Ramatu and Akotia from Kariba School used traditional songs as means of making learning meaningful in their kindergarten classroom. However, the teachers did so for different reasons.

Ramatu: I use traditional songs in class to help the children integrate their learning experiences because, at the end of every lesson, I select some key issues that I emphasise in the lesson and compose a song. As we sing the song, we emphasise these issues, we jump, dance and shake our bodies in line with the lyrics of the song.

Akotia: It helps in building a child's vocabulary because while singing children role play some of the words in the song and this helps promote the language development of the children.

For Ramatu, traditional songs acted as a nexus for the integration of children's learning experiences because it provided an opportunity for children to use play-based activities to emphasise key concepts that characterised a particular lesson. However, Akotia believed that traditional songs promoted children's language development because it provided an opportunity for children to role play certain words.

Moreover, these teachers had different views regarding the kind of traditional songs that are effective for promoting children's development.

Ramatu: I think children are always eager to engage in activities which are of interest to them. So, I use traditional songs which are popular in the communities of the children. But I alter it a bit to suit the activity that we are doing in class to make the activity interesting so that I can get the children involved in what we are doing.

Akotia: ... It should have an element of activity in it so that the child can do the practical aspect of it by acting out the meaning of the words emphasised in the song and once the child does this he or she will always remember.

For Ramatu, using traditional songs which were popular in the children's communities made the activities in class appealing to the children. However, Akotia perceived that traditional song when acted out improved children's retentions. Thus, traditional songs appear to play attitudinal and conceptual roles in pedagogy.

\section{Traditional rhymes as effective pedagogy}

Teachers at Kariba School used traditional rhymes as means of interpreting and applying DAP in their kindergarten classroom, yet, the teachers, Ramatu, and Akotia spoke of varied reasons as to why this practice impacted children's development.

Ramatu: I use traditional rhymes a lot in this class because it makes lessons interesting to the children. It also gives them the opportunity to engage in activities which help them to 
understand what they are saying and what we are learning in class.

\begin{abstract}
Akotia: In this class, we do subject teaching, but I use rhymes sometimes at the end of every lesson to help the children integrate their learning experiences. The children learn better when I use this approach.
\end{abstract}

For Ramatu, a rhyme was an effective means of promoting children's development in kindergarten settings because it aroused children's interest in a lesson and provided an opportunity for children to engage in activities to promote their understanding of concepts taught in class. For Akotia, a rhyme promoted children's understanding of concepts taught in class because it provided an opportunity to integrate their learning experiences.

Regardless, both teachers believed that a rhyme would have such a desired effects on children's development, only if it aligned with the social context of children.

Ramatu: Most of the rhymes we recite in the class have English origin, so I usually introduce certain cultural elements which are familiar to the children into the rhyme to enable them to understand what they are saying.

Akotia: For me to help children understand what they are saying in class and their environment. So, all the things mentioned in the rhyme should be things they see every day in their environment.

For both Ramatu and Akotia, a rhyme that children recited in a kindergarten classroom could only have the desired impact on children's development if the socio-cultural elements within children's immediate environment were integrated into it. They further perceived that the impact of such a rhyme on children's development was twofold; first, it helped children understand concepts taught in class, and second, it helped them understand their world (i..e. 'sasa').

Overall, then, evidence from the data appear to suggests that the sociocultural context of children is a key determinant of what these teachers believed is appropriate for children to learn. However, there appears to be diversity regarding how each of teacher made learning relevant to children in this rural kindergarten setting, at the very least in the illustrative examples they provided.

Across case analyses: Pedagogy in children's socio-cultural setting (Tata and Kariba Schools)

To further understand the ways in which kindergarten teachers employ children's socio-cultual contexts as meaning of helping children understad their world. developmentally appropriate practices, across-case analyses (by school) is reported next. As might be expected, some of the themes reported within each case were unique to that case. However, most themes were shared by all four teachers in the study, regardless of the school setting in which they taught. Thus, to consider the analyses of the four teachers' (i.e. Kate and Sophia at Tata School, Ramatu and Akotia at Kariba School) Thus, the summary of the themes emanating from the research questions across the cases are presented as follows.

Likewise, participants in the two cases perceived that children's sociocultural contexts constitute the basis for the selection of learning materials for kindergarten classrooms. To help children understand concepts taught in class, the teachers in both cases took similar factors into consideration when selecting teaching and learning materials. For instance, Kate and Sophia at Tata School, as well as Ramatu and Akotia at Kariba School, shared that children's outof-school experiences informed the selection. 
Looking across both cases, three teachers out of the four, saw storytelling as a means of promoting the moral development of children within the kindergarten settings. For instance, the participants from Tata School, Kate and Sophia, as well as Akotia from Kariba School, valued storytelling because of its impact on children's moral developments whereas Ramatu at Kariba School perceived it as a tool for the development of children's retentive memory and listening skills. Thus, the responses of the teachers suggest that storytelling impacted children's learning in diverse ways.

The participants across the cases had different and specific reasons for valuing traditional songs but, regardless of the context, (Tata School or Kariba School), the participants saw traditional songs as important. However, it appears that for teachers in an urban setting (Tata School), traditional songs provided a context in which to support children's language learning. Teachers in the rural setting (Kariba School) appeared to view traditional songs as a means to integrate children's learning experiences. It, therefore, appears that traditional songs have a twofold impact on children's learning across the cases. Interestingly, teachers at Kariba School spoke of traditional rhymes separately from songs, although, they believed that they supported children's development in similar ways.

\section{Discussion}

As the findings revealed, these four Kindergarten teachers' perceived their pedagogical practices to be socioculturraly determined and observations, albeit limited, point to fidelity with their application in the classrooms. While the ways in which these teachers situate early childhood pedagogy in these two kindergarten classrooms varied with regard to specifics, a common thread running through the five themes (i.e. selection of learning materials, and storytelling, traditional songs, and traditional rhymes) was the interrelationship between pedagogy and the children's socio-cultural context. These teachers, whether urban or rural, appeared to choose particular learning materials, and specific oral traditions (e.g. storytelling, rhymes and songs) because of their perceived impact on making learning relevant and meaningful to children. This, in turn, suggests that these kindergarten teachers seemed to use children's socio-cultural practices that are both informed by and support children's development in diverse ways.

As explained by the participants in both cases, children's background constituted the basis for the teachers' selection of some of the teaching and learning materials. In doing so, it appeared they believed that teaching and learning in kindergarten classrooms become relevant and useful to children if they are focused on children's sociocultural contexts (Copple and Bredekamp, 2009). All four teachers reported using learning materials such as bottle tops, shells, clay, and leaves from various kinds of plants to engage children in various learning activities. They argued, as they did for the language of instruction, that if they used learning materials that are familiar to children, it helps them understand the concepts addressed in class. However, unlike when discussing the language of instruction, these teachers did not explicitly state whether these specific materials were indeed commonplace in individual's homes and communities but rather were perceived to be familiar (i.e. child-friendly). In addition, in the rural school (Kariba), using such materials appeared to be somewhat influenced by a lack of commercial resources (e.g. coloured counters). By using materials readily available in both settings, these teachers tend to provide a familiar learning environment for their children which in turn, further suggests that these teachers seemed to recognise at least, tacitly that "clear grounding in a location 
gives us the confidence to engage with knowledge from other locations as we deconstruct and reconstruct with our purposes" (Canagarajah, 2005 p.15). In addition to these materials being developmentally appropriate from a socio-cultural perspective, these teachers also revealed that they used learning materials that are "familiar to the children to promote their understanding of their environment". Igamu and Ogiegbean (2007) claim that it is detrimental to provide children with an education that has no bearing whatsoever on their lives or which does not enhance their understanding and dominion of their environment. Thus, these teachers' use of contextappropriate materials in reciprocal ways with their children, at the very least, implicitly enhance and promote children's development. Moreover, the teachers' use of such familiar learning materials in the classrooms underscores the teachers'interpretation of DAP whereby they provide opportunities for the children to engage in hands-on physical activities to promote their development. This finding concurs with the assertion by Kamii and DeVries (1993) that young children are more mentally active when they are physically engaged in learning content as they try to figure out how to accomplish a task.

All the four participants of the study identified storytelling as a means of helping children develop morally. However, Ramatu further linked storytelling to children's cognitive development, and thus indicated one way they interpreted and applied DAP in their classrooms. In particular, this finding points to the significant role developmentally appropriate practices play in children's moral development in Ghanaian Kindergarten classrooms. Indeed, it appears, these teachers guided children's moral development, in both the rural and urban settings, by the coding of traditional values into stories, the discussions that ensue after a story has been told, and the narration itself.
However, in a religiously pluralistic society like Ghana, the issue of how to inculcate moral values into young children in kindergarten settings has been a contested one for a very long time. More recently, based on research (Hunter and Elder, 2010) showing that storytelling impacts children's moral development, early childhood educators and other stakeholders such as kindergarten teachers have incorporated storytelling, which is a cultural practice within traditional Ghanaian settings, as a pedagogical tool in the kindergarten curriculum in Ghana. Thus, it is not surprising that these teachers would identify it as such, because of the individual commitment of some of the teachers (e.g. the teacher who dressed like one of the characters in the story). However, what is striking regarding the current study was that only one of the participants (e.g. Ramatu) pointed to the link between storytelling and children's cognitive development:

Storytelling helps to develop the retentive memory of children because as children listen to stories, they narrate it to others. And as they do that at a point, they will be able to narrate the story exactly as they heard it.

While it remains unclear why moral implications of this developmentally appropriate practice overshadowed the cognitive, it appeared associated with the value accorded it in the larger socio-cultural context in which these teachers and children lived.

As revealed by the participants of the study, traditional songs served as developmentally appropriate means of enhancing and promoting children's development in multiple ways. However, the developmental needs of their children determined how the teachers used the songs in kindergarten settings. For instance, traditional songs which had English language letter sounds embedded them provide an opportunity 
for the teachers at Tata school to use a developmentally appropriate means to introduce certain sounds in the English language to their children, which in turn enhanced their pronunciations skills. While the use of traditional songs, which highlighted the consequences of people's actions and inactions to promote children's moral development is less surprising, it again points to the sociocultural relevance of this teacher's (Kate) developmentally appropriate practices. In contrast, however, only the participants from Kariba School, spoke of traditional rhymes as a means of promoting their children's development in diverse ways. Interestingly, although, the rhymes were traditional English rhymes, these teachers perceived the rhymes as developmentally appropriate for integrating children's learning experiences as well as arousing children's interests in the lesson. Of importance here, is how these teachers introduce culturally relevant elements into the rhymes (i.e. things they see every day in their environment) to enhance their appropriateness. Modifying and generating rhymes this way then supports the long-held notion children's interests should be one of the bases for designing learning activities for children in kindergarten settings (Bredekamp, 2014). Whether differences in teachers' experiences or compliance with the mandated curriculum and the developmental needs of these children, explains why these teachers incorporated storytelling, traditional songs and rhymes in these kindergarten classrooms, they did so in culturally respective ways based on what appeared to be and intimate knowledge of their children's lives.

\section{Conclusion}

Based on the major themes discussed above, some key points were notable about the use of socio-culturally context based early childhood pedagogy in kindergarten classrooms. For instance, it is apparent from the study that the socio-cultural backgrounds of the children and their contexts (language, learning materials, traditional songs, rhymes, curriculum and pre-designed materials) influence on how early childhood pedagogy was designed and implemented in kindergarten classrooms. However, within this, there exist diversity and difference.

Socio-culturally infusedkindergarten pedagogy is recognised as an effective means of harnessing children's potentials in kindergarten settings. Considering the adoption of culturally- infused pedagogy in many kindergarten settings globally, nevertheless, empirically based evidence regarding its impact on children's learning in Ghanaian kindergarten settings is limited. This study's findings provide insights into how pedagogy can be adapted and applied in kindergarten settings to support the development of children from diverse sociocultural backgrounds. Further, this has implications on how culturally-based kindergarten pedagogy is organised and implemented in kindergarten classrooms with attention to the local sociocultural context. The study's findings bring to our awareness the richness of sociocultural contexts in curricular opportunities for teachers to engage children in kindergarten classrooms activities which would enable children to understand what they are learning which would, in turn, develop children's problem-solving abilities. Thus, the study's findings reinforce and in a limited way extend the constructivist theories that consider sociocultural contexts of children as key determinants of kindergarten pedagogy and the way it is applied in kindergarten classsrooms.

The study's findings have implications for future adoption and adaptation of instructional models such as early childhood pedagogy that are often brought to contexts different from where they were formulated. Moreover, the alignment that was detected between 
early childhood pedagogy and the sociocultural practices of Ghanaian Kindergarten teachers is a course for calibrated approach to embracement of foreign authored models.

\section{References}

Boeije, H. Analysis in qualitative research. London: Sage Publications, 2010.

Bredekamp, S.; Copple, L. Developmentally appropriate practices in early childhood programmes, serving children through age eight. Washington, D.C., National Association for the Education of Young Children, 2007.

Bronfenbrenner, $U$. The ecology of human development. Cambridge, MA: Harvard University Press, 1978.

Canagarajah, A.S. Dilemmas in planning english/vernacular relations in post-colonial communities. Journal of Sociolinguistics, v. 9, no. 3, p. 418-427, 2005.

Dewey, J. The child and the curriculum. Chicago: The University of Chicago Press, 1902.

Erickson, F. Qualitative methods on research in teaching. In: Merlin, W. C. (Ed.). Handbook of research in teaching. New York: MacMillan Publishing, 1995. p. 119-161.

Farquhar, S.; White E. J. Philosophy and pedagogy of early childhood. Educational Philosophy and Theory, v. 46, no. 8, p. 821832, 2014.

Gananathan, R. Implications of full day kindergarten programme policy on early childhood pedagogy and practices. International Journal of Child Care and Education Policy, v. 5, no. 2, p. 35-45, 2011.

Hedges, H.; Cullen, J. Participatory learning theories: A framework for early childhood pedagogy. Early Child Development and Care, v. 82, no. 7, p. 921-940, 2012. https://doi.org/10.1080/03004430.2011.59 7504

Harris, K. I. Developmentally universal practice: Visioning innovative early childhood pedagogy for meeting the needs of diverse learners. Early Child Development and Care, v. 185 , no. $11 / 12$, p. $1880-1893$,
2015. https://doi.org/10.1080/03004430. 2015.1028395

Hunter, C.; Elder, D. The role of storytelling in understanding children's moral/ethic decision-making. Multicultural Perspective, v. 12, no. 4, p. 223-228, 2010.

Iyamu, F. O. S.; Ogiegbaen, E. A. Parents and teachers' perception of mother-tongue medium of instruction in Nigeria primary school schools. Language, Culture and Curriculum, v. 83, no. 1, p. 300-321, 2007.

Kamii, C.; DeVries, R. Physical knowledge in preschool education: Implications for Piaget's Theory. Washington, DC: National Association for the Education of Young Children, 1993.

Mazzocco, P. J. Empowerment through pedagogy: Positioning service-learning as an early childhood pedagogy for pre-service teachers. Early Child Development and Care, v. 185, p. 11-12, 2015.

Murray, J. Early childhood Pedagogies: Spaces for young children to flourish. Early Child Development and Care, v. 185, no. $11 / 12$, p. 1715-1732, 2015. https://doi.org/10.1080/03004430.2015.10 29245

Piaget, J. The child's conception of number. London: Humanities Press, 1952.

Rogoff, B. The cultural nature of human development. Oxford: University Press, 2009.

Siraj-Blatchford, I.; Sylvia, K.; Muttock, S.; Gilden, R.; Bell, D. Researching effective pedagogy in the early years. London: Queen's Printer, 2002. (Research report, 356).

Thompson, M. A multi-case study of instructional decision-making processes of teachers in kindergarten classrooms within the Cape Coast Metropolis, Ghana. Revista Brasileira de Gestão Ambiental e Sustentabilidade, v. 5, no. 9, p. 27-40, 2018. https://doi.org/10.21438/rbgas.050902

Veale, F. Pedagogical Approaches in Early Years Education. Proceeding of the South Devon College Inaugural Research Showcase, 2014.

Vygotsky, L. Mind and society: The development of higher psychological 
processes. London: Harvard University Press, 1978.

Winterbottom, C.; Mazzocco, P. J. Empowerment through Pedagogy: Positioning service-learning as an early childhood Pedagogy for pre-service teachers. Early Child Development and Care, v. 185, no. 11-12, p. 1912-1927, 2015. https://doi.org/10.1080/03004430.2015.10 28396

CC License information: This is an open-access article distributed under the terms of the Creative Commons Attribution License, which permits unrestricted use, distribution, and reproduction in any medium, provided the original work is properly cited. 